\title{
Objective Possibility as Urban Possibility: Reading Max Weber in the City ${ }^{1}$
}

\section{Authors: Meirav Aharon Gutman and Moriel Ram}

\begin{abstract}
By employing Max Weber's (1949) concept of objective possibility, this article offers a theoretical conceptualization of a methodological approach to studying roads not taken in divercities. The article incorporates Weber's insight from the realm of sociohistorical analysis into an analysis of urban environments. In search of 'other' possibilities of planning, the article presents a case study of the informal synagogues set up in Israel by members of Judeo-Arab communities. In this case, the possibility that was not actualized is 'intimate publicness,' which encompasses new forms of organizing the relationship between private and public spaces.
\end{abstract}

\footnotetext{
${ }^{1}$ This fieldwork-based study could not have been carried out without the trust and generosity of the founders of the synagogues and their families, who are striving to maintain their family heritage. The authors are grateful to them for allowing them to enter the intimate public spaces they created. The authors would also like to thank Haim Singer, who is responsible for photography in the Technion's Faculty of Architecture and Town Planning, and Yelena Landau, for her assistance with the architectural analysis of the materials.
} 


\section{Introduction}

For some time now, scholars of urban studies have been striving to document processes of erasure, population displacement, and spatial destruction (Staples 1999; Slyomovics 1998). This exploration has highlighted the loss of people's ability to plan their built environments in their own social and spatial languages.

This article is written from the perspective of "becoming local" and is based on the premise that, even under extreme conditions of inequality, minority groups have not lost their agency and have not ceased planning and shaping their environment. Spatial destruction and social marginalization are never complete products but rather continuous processes that generate different layers of subjectivity. It is this multiplicity and the ways in which it can be bared, undermined, and unraveled that are of particular interest here.

By employing Max Weber's (1949) concept of objective possibility, the paper offers a theoretical conceptualization of a methodological approach to studying roads not taken in environments that have undergone processes of spatial erasure. Max Weber's socio-historical research seeks to understand historical turning points in culture, economy, and politics, which guide and facilitate his critical thinking. This article highlights two principles of Weber's work: his tendency to focus on junctions and his effort to understand the circumstances under which one specific road is taken and others abandoned (Weber 1949, 184).

Weber rejects deterministic perspectives, which regard historical progress as a definitive process $(1949,165)$. Instead, he seeks to “re-open” time by positing several possibilities that existed at different points in the past but that eventually lost out to the single option that was ultimately actualized and written into history. In this way, Weber employs the concept of objective possibility in the study of critical historical junctions 
by arguing that identifying such crossroads is vital for the development of critical perspectives in the social sciences. According to Weber (164), the question of 'what might have been' is far from futile. After all, if it is indeed the victors who write history, then Weber's notion of objective possibility represents an attempt to draw out the stories of the vanquished. In this way, 'roads not taken' can be understood as primarily spatial metaphors that spark imagination of paths leading to a space of possibilities.

This article incorporates Weber's analytical insight from the realm of sociohistorical analysis into an analysis of spatial erasures in urban environments. In doing so, it transposes objective possibility from the archive to the city and use it to enrich the field of urban study with an analytical framework that is at once a theoretical construct and a methodological toolbox for deciphering contemporary urban spatialites. Objective possibility, both as a theory and a methodology, has the potential to contribute to urban design and urban planning, as is demonstrated below.

This article is based primarily on a case study of the informal synagogues established by members of the Judeo-Arab population of the city of Acre, which, following the establishment of the state of Israel in 1948, became a mixed urban environment. The informal synagogues offer a promising arena for elaborating "the road not taken.” Although many such synagogues founded by the first generation of Judeo-Arabian immigrants exist throughout the country, they were never recognized as social and cultural frameworks requiring state recognition, adoption, and subsidy. They were also not acknowledged by professional elites as a source of learning and inspiration for the country's new architecture. In addition, a sense of great uncertainty exists regarding what will happen the day after their founding fathers pass. As a result, they have remained informal, temporary, and fragile entities. 
Of the numerous diverse forms of informal synagogues encountered in the research, this article focuses on three specific types: the synagogue operating within a private home, the synagogue operating in a liminal space in an apartment building, and the synagogue constructed as a public building that also encompasses "private" functions” (such as a kitchen and a space for events).

The study of these fragile social and urban structures, which did not play an influential role in modern architecture and planning in Israel, is actually a study of what might have happened. The possibility that was not actualized is that of intimate publicness,' which suggests new ways of organizing the relationship between private and public - not as a dichotomy but rather on a scale. In this context, the article considers: 1) the development of the public within domestic space; 2) the organization of public and private within liminal space; and 3) the introduction of the domestic into public space. These three configurations are located at different points on a scale ranging from the intimate to the public. From this perspective, this article is an attempt to understand this unique form of socio-spatial organization, which runs counter to the modern architectural zeitgeist. It was written against the clock, in an attempt to capture the phenomenon before its possible disappearance.

The article consists of two parts. The first presents the concept of objective possibility both as a theory and a research method and formulates four stages of research for implementing it. The second applies the method of objective possibilities to the case of informal synagogues in an Israeli mixed city in an attempt to demonstrate the usefulness and the sociological imagination of the concept. The discussion asks how the analytical exercise of objective possibility can be of assistance to designers and planners as practitioners. Intimate publicness as an objective possibility, it will be argued, stands both to challenge the manner in which planners and designers organize 
the private-public divide and to impact the way in which conservation architects work on the built environment.

\section{The Concept of Objective Possibility}

\section{A. Max Weber and Objective Possibility: Out of the Archive and into the City}

Weber's concept of objective possibility offers an analytical approach to the investigation of socio-historical junctions that involves deconstructing the chronology of events and reconstructing them in a new and critical manner. From a Weberian perspective, and in accordance with Weber's struggle against deterministic thinking, the question of "what might have happened, if" is not at all pointless (164). After all, asking this question forces consideration of alternative scenarios, or possibilities. In this way, Weber resists the perception of history as an arbitrary flow. If it seeks to be a science, he $(1949,174)$ argues, history must recognize the existence of other possibilities.

But what exactly are these “possibilities?” Weber calls for understanding possibilities as imagined constructions whose constitution requires the interweaving of abstractions into concepts. For Weber, concepts are interpretive tools that are important for both causal analysis and comparative research, both of which lie at the core of the Weberian approach to learning social history. The governance of these concepts is articulated in his concept of the ideal type (1959): an abstract model based on concepts that seek to express a social structure in its ideal form.

Although Weber rejects the possibility of historical analysis proceeding like a laboratory study in which all data is fully monitored, he nonetheless holds that all its components must be completely isolated and considered separately, including their relative influence and significance and the way in which they influence the outcome. 
For Weber, what is important is the end result: the effect produced by a particular combination of components. His focus is not on intentions, motivations, declarations, or narratives, but rather on the action enabled by a certain set of conditions.

Weber borrowed the notion of objective possibility from psychologist and statistician Johannes von Kries (1853-1928), whose ideas built upon an established tradition in German legal philosophy (Ringer 2002, 163; Heidelberger 2001). According to Ringer, "Weber was neither a positivist nor a neo-Idealist, but a causalist" (Ringer 2002, 163).

Weber distinguishes between components that are "external” to personality and experience and those that are "internal" to it, and calls for focusing only on the external (i.e., the objective). As motivations, intention, and interpretation are all embodied in an action itself (Ringer 2002, 169), the emphasis should be placed on the action and its effect.

Causality lies at the heart of a broader methodology to which Weber refers as counterfactual analysis, which poses the question of whether it is possible to isolate a single cause whose removal would alter the final result (Weber 1949, 117; Reiss 2009, 712). When social scientists explore the causal connections between, and the reciprocal influences of, the isolated components, their greatest challenge is to determine that such causal connections do, in fact, exist.

\section{B. Bringing Weber to the City}

In an effort to make an objective possibility-based approach accessible to the urban studies community, this article proposes the following four stages of urban investigation: 


\section{Selection of the site to be examined: A concrete place of multiplicity}

The guiding principle is that the starting point of any investigation should be a physical place of multiplicity, that is, a place that embraces the many layers of time, architectural trends, materials, and languages. Multiplicity ensures an attractive site for investigation, as it is organized in space and presents social opportunities and possibilities that are grasped in spatial terms. Such spatially manifested multiplicity is the key condition when deciding upon a site for examination.

\section{Identification of a road not taken: Illuminating 'objective possibilities'}

How is it possible to chose a site that facilitates identification of an objective possibility? First, the space in question must not be abstract but rather a concrete living space. What is important here is the meaning created at the meeting point between human action and the built environment. It is therefore helpful to choose spaces that are 'off the books,' meaning, located on the periphery of hegemonic groups and/or formal spaces.

Being located in peripheral areas is what allows people to act 'differently.' In many cases, they are spaces that at first glance may appear wretched and do not betray the fact that they also encompass an alternative way of understanding the built environment. It is also helpful to choose spaces in which entrepreneurs, real estate professionals, and other forces of development have not yet been active and that still contain urban logics from outside the realm of capitalism.

\section{Isolation of components and the definition of concepts}


The empirical knowledge acquired, reflecting the multiplicity of the place under investigation, is analyzed in two stages. The first involves deconstructing the concrete place of objective possibility into components and attempting to determine those that constitute its fundamental elements. The second involves conceptualizing these elements. The process of deconstruction and generalization facilitate a higher-level analysis of 'other' spaces. Conceptualization and generalization are the crux of the movement from empirical analysis to theoretical explanation.

4. Causal analysis: Once sufficient abstract concepts have been identified, an attempt is made to determine the causal relations between them. This stage considers how one component affects the other. The ability to identify causal relationships is the most challenging aspect of the research process, and objective possibility analysis helps identify such links, making this its main contribution. The conditions in which these components affect one another are of critical importance in this stage, and deciphering these conditions is critical to understanding causal contexts.

\section{Objective Possibility as Urban Possibility: An Expanded Case Study}

The first section of this article proposes a research format with the capacity to effectively address different spaces, populations, and periods. However, this article also seeks to demonstrate this format's application to a given place and time, including its usefulness and its limitations. To this end, the second part of this article applies the proposed research format to the case study of informal Mizrachi synagogues in a mixed city in Israel. 


\section{A. Selecting the Site: Acre as a Concrete Place of Multiplicity}

Acre, the site selected for examination, is a city of physical and social multiplicity in terms of both time (multiple histories) and place. As such, it is a city that embodies "other" opportunities and possibilities. Acre is located in the Mediterranean coastal plain in northern Israel (Map 1) and was historically populated predominantly by Muslim and Christian Palestinians, as well as a small Jewish population (Phillipp 1990; Waterman 1971).

The Ottoman governors of Palestine attributed little importance to the construction of a regulated planning apparatus to facilitate development of the built environment. Urban change in the city relied primarily on the entrepreneurship of local governors such as Zahir al-Umar al-Zaydani, who governed Northern Palestine, Acre included, during the eighteenth century. From the mid-nineteenth century onward, Ottoman planning authorities began to pay greater attention to civilian issues, as opposed to their previous primary concern for military fortifications. Social and economic changes such as regional economic developments, the construction of a railway, and the beginnings of industrialization led the Ottomans to invest greater effort in the establishment of open urban spaces rather than its former walled, enclosed built environment.

This shift in planning focus impacted Acre's spatial development. The town consisted primarily of an old walled core, which stood on the remains of the Crusader city of St. Jean d'Acre. The first modern planning scheme for the city was formulated by German railway engineer Gottlieb Schumacher in 1909. The plan aimed at expanding Acre's built environment using a gridiron pattern and was drawn up at the request of the Ottoman authorities. Schumacher's plan served as a template on which 
the British, who succeeded the Ottomans in 1917, based the further spatial planning of the city, as manifested in the Kendall plan, which was formulated in 1940 and approved in 1946. The British plan focused on restoring unused areas in the walled quarter, controlling unrestrained building development, regulating housing densities, and the introduction of zoning. Zoning, a preferred tactic of the British planning authorities, was also dominant in the 1930 scheme for Jerusalem; it was applied to Acre because the planners regarded the city as presenting similar challenges. The external borders of the city were delimited by the Mediterranean shoreline in the west, the Palestinian villages in the east and the south, and the government experimental farm in the north (Waterman 1971).

Figure 1: The City of Acre 


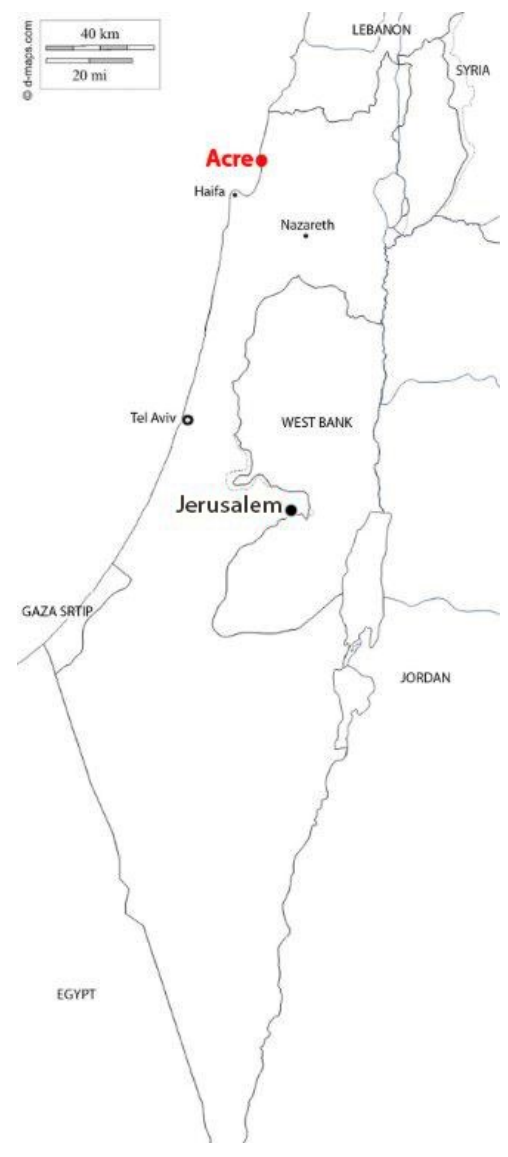

Acre's fundamental transformation occurred after the 1948 war, when most of its population, which at the time consisted of some 15,000 Palestinians residents and 20,000 refugees from the surrounding area, were expelled by the victorious Israeli forces, with only approximately 4,000 remaining in the city (Abbasi 2010).

Israeli state authorities reshaped the city in an effort to create "a Jewish presence in what was basically a hostile area" (Waterman 1975, xvi). To this end, Israel repopulated the city with Jewish immigrants from other parts of the Middle East and North Africa - a social group that has come to be known as "Mizrachi” Jews (Torstrick 2000). Mizrachi Jews whom the state settled in Acre underwent a process of cultural erasure, based on state authorities' view of their ethnic identity as backward and incongruous with the modern state of Israel. 
In 1954, the Acre city municipality drew up a comprehensive plan, which incorporated elements of most previous planning schemes and envisioned a town based on a series of neighborhood units (Waterman 1975). Some of the city's modern neighborhoods were planned and built on the sites of abandoned Palestinian villages and were designed to become suburban environments. While the majority of the Palestinian population was pushed into the city's walled quarter, the nearby area, built in accordance with Schumacher's 1909 plan, slowly evolved into a mixed built environment in which the remaining Palestinian residents lived side by side with new Jewish immigrants. Afterwards, during the 1960s and 1970s, planning restrictions in this area drove many Palestinians into neighborhoods that were populated predominantly by Jews (Garzuzi 2006).

After 1948, Acre’s local identity underwent dramatic change as a result of a process of double erasure that diminished Palestinian, or Arab, identity on the one hand and Mizrachi identity on the other. The erasure experienced by both populations, however, has by no means been symmetrical. Mizrachi Jews were incorporated into the state-building project as part of the dominant Jewish majority, and they enjoyed a social position that most Palestinians in Israel lack. Indeed, any signs of a resurgence of Palestinian identity in the city are regarded as a threat to its Jewish identity, whereas the presence of Mizrachi Jews in the city is considered vital to preserving a Jewish demographic majority (Ram and Aharon-Gutman: 2017).

\section{B. A Road not Taken in Acre: Illuminating an Objective Possibility}

In this way, the city constitutes a rich space abounding with possibilities and opportunities. The challenge, however, was which specific social and physical setting 
to choose and how to go about selecting a site that would allow identification of an objective possibility.

One of the guiding principles employed in this case is a concern with marginal groups, as objective possibilities are often found in the context of groups operating below the institutional radar: those lacking formal education, state funding, supervisory mechanisms, and regulation. In the present case, the parties in question are diverse groups who immigrated to Israel from different countries in Asia, the Middle East, and North Africa and whom were placed under the single category of Mizrachim, or, to use a term proposed by academic scholars, “Arab Jews.”

As already noted, most of Acre's Jewish immigrants belong to the broader category of Mizrachim, which also includes Jews from Middle Eastern countries (Torstrick 2000). Many Mizrachi Jews settled in Israel’s 'mixed' cities, from which the majority of the Palestinian population either fled or was expelled during the 1948 war (Weiss 2011; Piroyanski 2014). Both types of localities - development towns and mixed cities - rapidly emerged as Israel's social periphery and were significantly marginalized by the state in resource allocation and planning policies (Tzfadia \& Yacobi 2009).

Mizrachi Jews were also concurrently marginalized in the labor market and were therefore precluded from playing a significant role in planning their own environment. Due to the suppression of their cultural identity and the powerful political hegemony of European Jews in the country (Chetrit 2010), which regarded modernity as a secular project that needed to disavow religion in order to achieve progress, Mizrachi communities espoused a different conceptualization of modern life: one in which religion was maintained and incorporated into everyday experience via personal practices, social gatherings, and communal institutions (Bilu 2000; Leon 2009). 
For these reasons, synagogues maintained particular importance in Mizrachi communities. As observed by feminist activist Iris Mizrahi: "When they closed all the doors on the Mizrahim, they forgot to close one - the door of the synagogue.” The synagogue was recognized as more than just a lived museum but also a space that sustains an ongoing present alternative to modern planning (Leon 2010).

Synagogues were characterized as a mirror of the Mizrachi community's organizational, economic, political, and spiritual condition and as an institution that plays a central role in the communal and political lives of many of these immigrant communities (Deshen 1972; Leon 2010; Weiss 2011). Over the years, synagogues have served as a primary site through which Mizrachi communities have moderated their experience as immigrants and negotiated their civil identity as citizens of the state.

Synagogues are dispersed throughout the city. Although information could not be obtained regarding their exact number, one official attested to having counted at least ninety edifices being used for this purpose, whereas an official list provided by the Acre Religious Council enumerated 'only' 63 registered synagogues. ${ }^{i}$ In contrast to this relatively high number, only seven mosques are operating in Acre today (Yaad 2008). As explained in the first part of this article, these synagogues are not perceived as sites of development and are not subject to the logics of capitalism or the academic profession. As a result, they encompass objective possibilities.

This gap reveals two fundamental aspects of the process of erasure that took place in Acre. First, both the Palestinian and the Mizrachi Jewish residents of the city underwent a process of erasure fueled by the consistent undermining of their cultural heritage, social status, and political power. Of the two groups, the Palestinians experienced greater exclusion from the Israeli public sphere, and their collective identity continues to be perceived as a threat by the Israeli state. Mizrachi collective 
identity, on the other hand, has been regarded as dated and unsophisticated and is only allowed to be cultivated through certain venues, most conspicuously religion.

As argued in the introduction to this article, physical and cultural erasure of the "other" was the product of the modernist regime, particularly in its colonial contexts. Religion frequently served as a tool for erasure through the encouragement of minorities to convert to Christianity and the Church's participation in the "white man's burden.” In many other instances, however, religion was perceived as an irrelevant dimension and was ignored. This disregard and neglect turned social and physical religious institutions into fascinating capsules of objective possibility.

Second, this gap reveals the nature of synagogues as an urban public institution that is a common sight in most parts of the city. As a representative of the municipal Religious Council explained, establishing a synagogue requires no act of compulsory registration. ${ }^{\text {ii }}$ Jewish law contains no obligatory directives regarding the planning and design of synagogues. A synagogue is first and foremost a community structure, and all it requires is the presence, in one space, of a Minyan - ten Jewish males over the age of 13 - to qualify the worship that takes place within its walls as 'public' prayer.

This flexibility allows significant space for creative acts on the part of different communities, which provides further justification for the selection of a religious institution as a place constituting an objective possibility. As noted by Kong (2002), literature on the urban geographies of religion has reflected increasing discussion on sites that are 'unofficially sacred' and thought to be contradictory to 'officially sacred' sites such as synagogues (and churches, temples, and mosques). Informality is an asset to studies in search of objective possibilities. The synagogues in Acre operate both with and without the formal recognition of the municipality. Few synagogues are housed within structures that were specifically designed to serve as such, and most operate in 
apartment buildings, commercial shops, or makeshift trailers. At the same time, the large number of synagogues in Acre and the relative ease with which they were established in diverse spatial environments are indicative of their importance as urban institutions.

Of the many informal synagogues in Acre, the research isolated three different types, each of which reflects a different kind of organization of the relationship between culture and the built environment. The three primary types of informal synagogues identified by the research are as follows: those operating in private homes, those operating in local bomb shelters, and those operating in designated structures built by the community. One representative case was selected for each type of informal synagogue, each of which contains within it an objective possibility whose nature is assessed here.

1. The Synagogue at Home - Abir Ya'akov: This synagogue (Figure 2) is located in a private residence and accessed via a small public road. It was founded by the father of the household who was once an active member of the National Religious Party. The synagogue initially served the Yemenite community, and the space also used to function as an afternoon religious school for the community (Heder).

Figure 2: The Synagogue at Home 

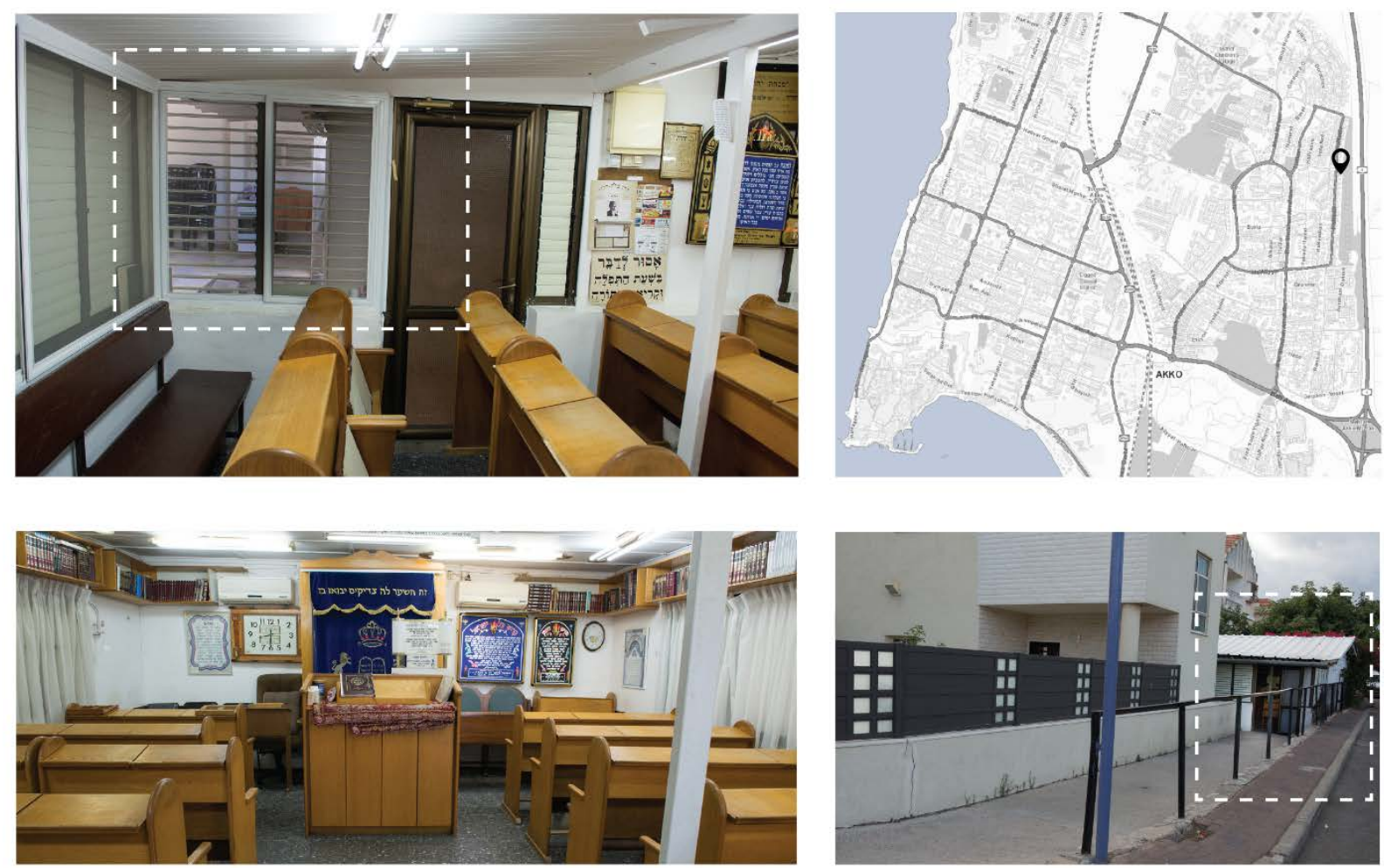

"Abir Ya'akov" Synagogue

2. The Synagogue in Liminal Space - Sha arei Shamayim: Serving primarily

Moroccan Jews, this synagogue (Figure 3) was established in the early 1970s by Eliyahu Avitan, who continues to function as its caretaker. At first, Avitan organized prayer services for worshippers in his community in a nearby retirement home. The municipality denied his bid for land to build a synagogue. Instead, he was issued a temporary permit to establish a synagogue in a public bomb shelter on the outdoor ground floor of a public housing project in the neighborhood - an arrangement that has remained in place for 30 years. The shelter's 40 square meters are divided into a main public area and a narrow space that functions as a kitchenette, a women's section for segregated worship, and a foyer. The synagogue was designed and constructed by its members, without the assistance of an architect or donors.

Figure 3: The Synagogue in Liminal Space 

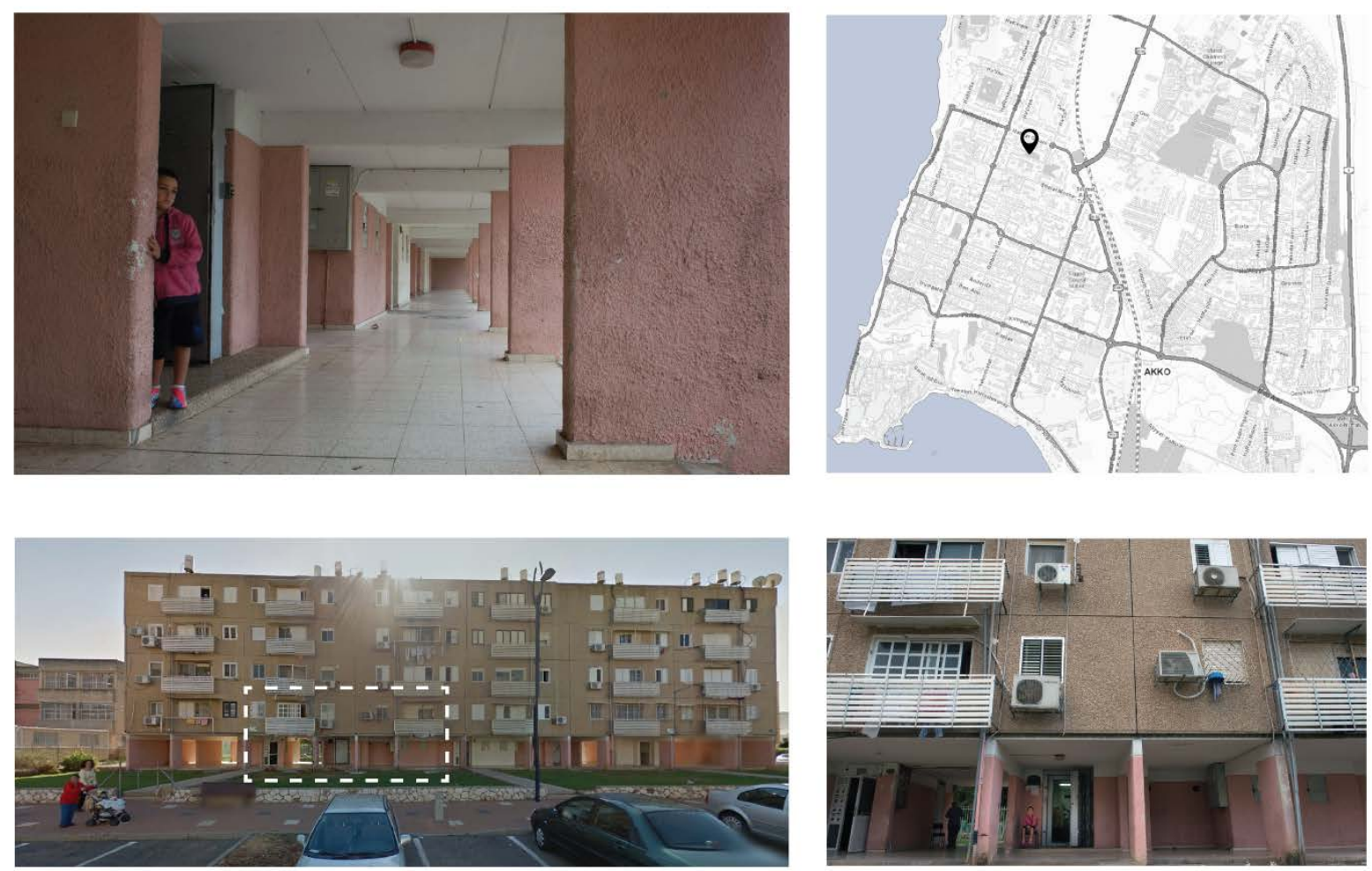

"Sha'arei Shamayim" Synagogue

3. The Synagogue as a Public Place - Or Torah: This synagogue (Figure 4),

which in its early years served the Tunisian community, is located in a fourstory building that also houses a hall for study and public events and a separate women's section. In this case, the community raised funds to hire an architect and an engineer, who drew up plans and obtained the necessary building permits. Once the basic foundation was standing, the architect was fired, because, according to synagogue founder Zion Ba’adash, he was “no longer required.” 
Figure 4: The Synagogue as a Public Place
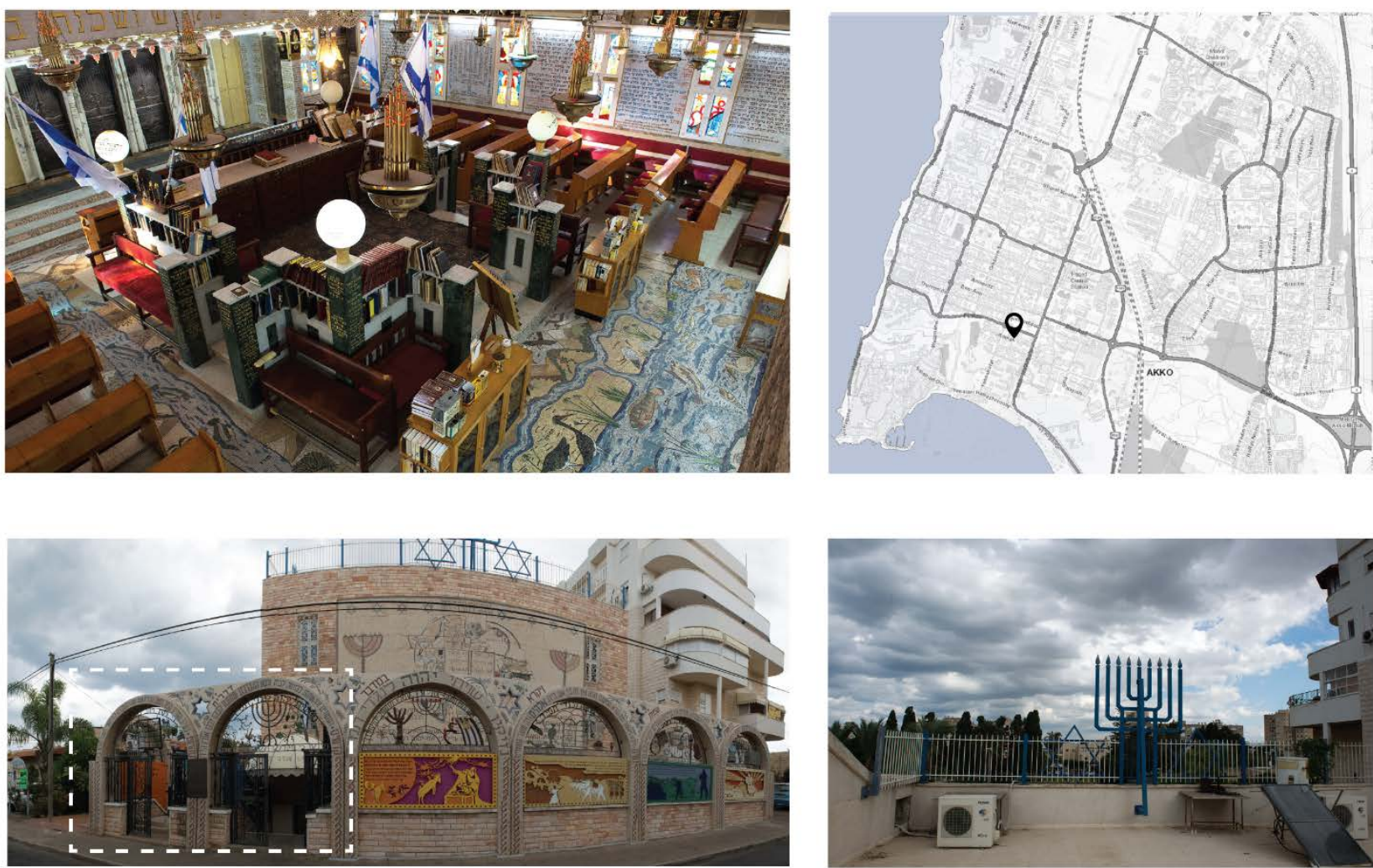

"Or Hatora" Synagogue

\section{The Components and Concepts of the Informal Synagogues in Acre}

As noted in the first part of this article, the third stage of the inquiry is one of conceptualization - that is, the identification of a primary concept that contributes to the analysis of the findings.

Ethnographic and architectural research conducted at each of these sites raised many issues. However, one concept that emerged repeatedly as a major challenge to these synagogues was the concept of 'public.' These three synagogues symbolize three different readings of 'public' and three alternative forms of organizing the relationship between private and public. The first is based on family, immediate and extended, whose door is always open to fellow members of their group of ethnic origin (in this case, Yemeni immigrants). For this reason, the synagogue is located in a private home, 
was initiated and planned by the fathers (as the leaders of the patriarchal family), and is internally designed and organized in a manner that is typical of synagogues in Yemen. As explained by a member of the third generation of the family that maintains the synagogue today:

Its builders were my father and my grandfather. It's Yemeni planning was according to the personal needs of the family. The form of seating is from Yemen. There were benches with cushions. If you delve into the heritage of Yemen, in some homes, the Passover Seder is conducted on the floor. When I will celebrate [the holiday] for the first time in my home, it will be on the floor, to feel the difference between what our ancestors outside of the Land of Israel felt - here, we are free. I want to give this to my children, to explain to them what it means to be free.

The interviewee speaks of the synagogue's internal organization and design, which was intended to meet the needs of the family. He also offers insight into the close relationship between the design of the space, its mode of use, and the system of values that the family wishes to pass on to its children - even under changing conditions. Sitting on the floor is perceived as the correct bodily position in the space in question for conveying messages of modesty, as a way of commemorating the fact that Jewish life cannot be taken for granted.

A tour of the synagogue revealed the sophisticated organization of the public within the private. An access road, which is fenced off from the family's home, was paved on the family's land. The synagogue is the point of connection between the family’s private aspect and public aspect. 
Figure 6: Spatial organization of the public within the private: Sha arei Shamayim Synagogue.
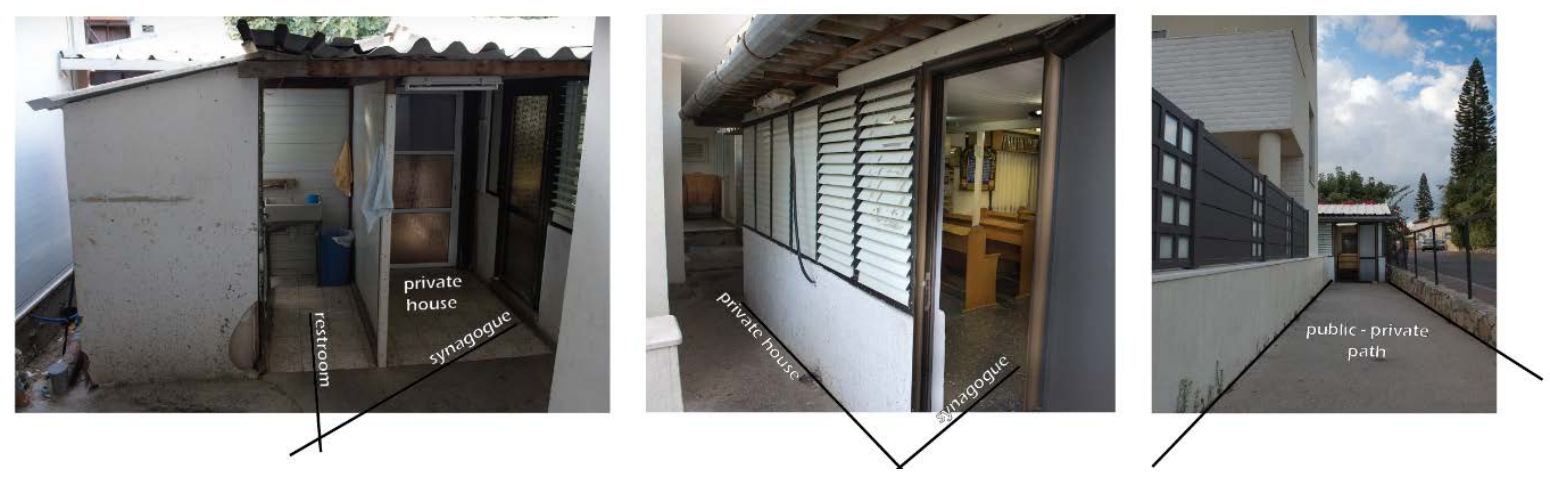

Also connected to the synagogue are rest rooms designated for synagogue visitors and a small entry area where refreshments can be served during the special events that are periodically held at the synagogue. In this way, the family established a complex structure of sharing and separation that enables members of the extended family and members of the ethnic group to congregate at one site.

The city building plans that were implemented in Israel based on modern urban planning are unable to process such physical and cultural structures, and family members have found themselves in the midst of an ongoing struggle against the authorities to get them to recognize the synagogue’s legality.

We expanded the synagogue without receiving authorization from anyone.

The construction of my own house was held up for six years due to the problems with the synagogue, because of the percentages of construction. They told me to get rid of the synagogue - I told them that I wouldn't get rid of the synagogue, even if it meant that I could not build my house. 
Today, I pulled a stunt. At the Regional [Planning and Building] Committee, I left the [structure classified] as a 'synagogue'. "Does it have parking?" they asked me. "Is there access for the disabled? The municipality objects.” I don’t ask them any questions. We established a synagogue, and it will remain a synagogue.”

With these words, the representative of the family illustrates the planning authorities' inability to incorporate such hybrid structures into their modernist system of regulations. After all, if it is a public building, it is subject to a host of laws, regarding, for example, access for the disabled. In addition, the family is not willing to give up its permitted percentage of building (meaning, its right to expand the built area within the lot and to continue to live on part of it) for the sake of the synagogue, and has requested authorization for additional construction to compensate for the construction that was devoted to the synagogue. Once again, this is an act that the planning authorities define as illegal. Therefore, on a formal level, the family representative changes how he refers to the structure according to need: sometimes it's a "shed" and other times it's a “synagogue.” Notable here is the fact that an objective possibility is sometimes viewed as illegal, facilitating its ongoing suppression by the authorities.

Figure 7: The plan for the lot before (the existing plan) and after (the new plan) the family’s struggle. 


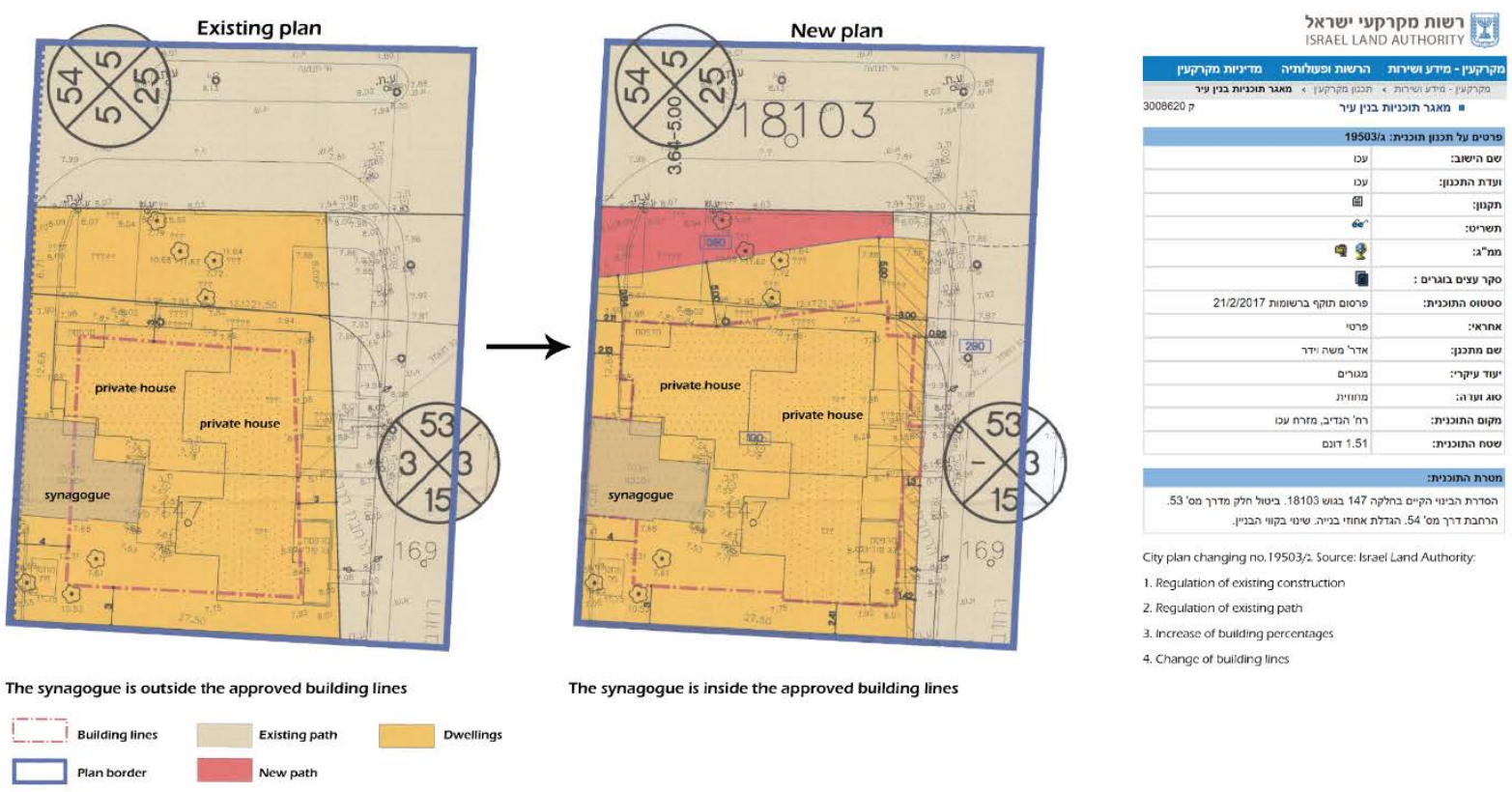

An analysis of the lot using architectural tools lends empirical validity to the information conveyed during the interview (source: Israel Lands Authority Plan 19503/c. The disparities between the existing plan and the new plan represent what the family achieved through their struggle: expansion of the lot's area to include both private and public functions, authorization of the access path as a private-public road, and increased building rights that will also allow the young generation to build their home on the lot.

This study encounters the synagogue at a unique point in its historical development. The grandfather and father in the family - who were the major figures responsible for founding the synagogue - have passed away, and with their deaths, the site's previous spirit was extinguished. At the same time, in the 1990s, a formal synagogue for members of the Yemeni Jewish immigrant community was established in the neighborhood, and the family found it difficult to round up a minyan (the aforementioned ten Jewish males over the age of 13 required for Jewish public worship) 
and to keep the synagogue functioning. In other words, the synagogue's public was starting to disappear.

These changes required the family to redefine and expand their public. Today, it promotes the synagogue as a synagogue for Mizrachi Jews from a wide range of countries in Asia and North Africa in an effort to ensure it's ability to continue operating. In this way, the intergenerational dynamics has changed the ethnic category as a category of definition, which raises the issue of 'the public' for re-discussion.

Another issue that is currently in the process of change is the site's design. The synagogue structure was inspired by Yemeni synagogues and took form when the family, like many other Mizrachi Jews, was experiencing major financial difficulties. Therefore, the form embodied by knowledge, tastes, colors, and preferences from "over there” in Yemen is actually perceived by family members as a meagre design implemented in a jumbled manner based on inadequate materials.

Before my father passed away, he told me that money had been designated and put aside so that we could do a renovation... We'll replace the furniture, the walls, and the windows to turn it into a modern synagogue with a new design. We saw a number of synagogues that we were enthusiastic about and that suited us.

In other words, despite the struggles involved in their establishment, the third generation appears to regard a “modern” space as key for the synagogue’s continued existence. 
Sha`arei Shamayim founder Eliyahu Avitan immigrated to Israel from Morocco in 1960 and settled in Acre with his wife and their six children. In the early 1970s, he bought a unit in a new, predominantly Jewish, neighborhood in northern Acre.

As noted above, Avitan's request for land to build a synagogue was denied, and he was advised to establish a provisional place of worship in the bomb shelter of his apartment block. This instance also reveals a unique mixture of private and public: the bomb shelter is a public space that is meant to serve all residents of the building and that is located on the building's outdoor ground floor, below the first level of residential units - that is to say, in the liminal area between private (the apartment in which the immediate family lives) and public (outside, the sidewalk, and the street). The stairwell and the outdoor ground floor are jointly owned by the building residents.

In the conditions of an immigrant society with meagre resources, such areas are frequently converted for uses that provide economic benefit, for family events, or for religious purposes. Here, too, the ethnic segregation - and the fact that during the period in which the synagogue was established most residents were Jewish immigrants of Moroccan origin - created a unique situation in which people could create liminal spaces in which private and public were not clearly distinct categories but rather extensions of one another. 
Figure 8: Sha `arei Shamayim, a view of the synagogue’s interior.
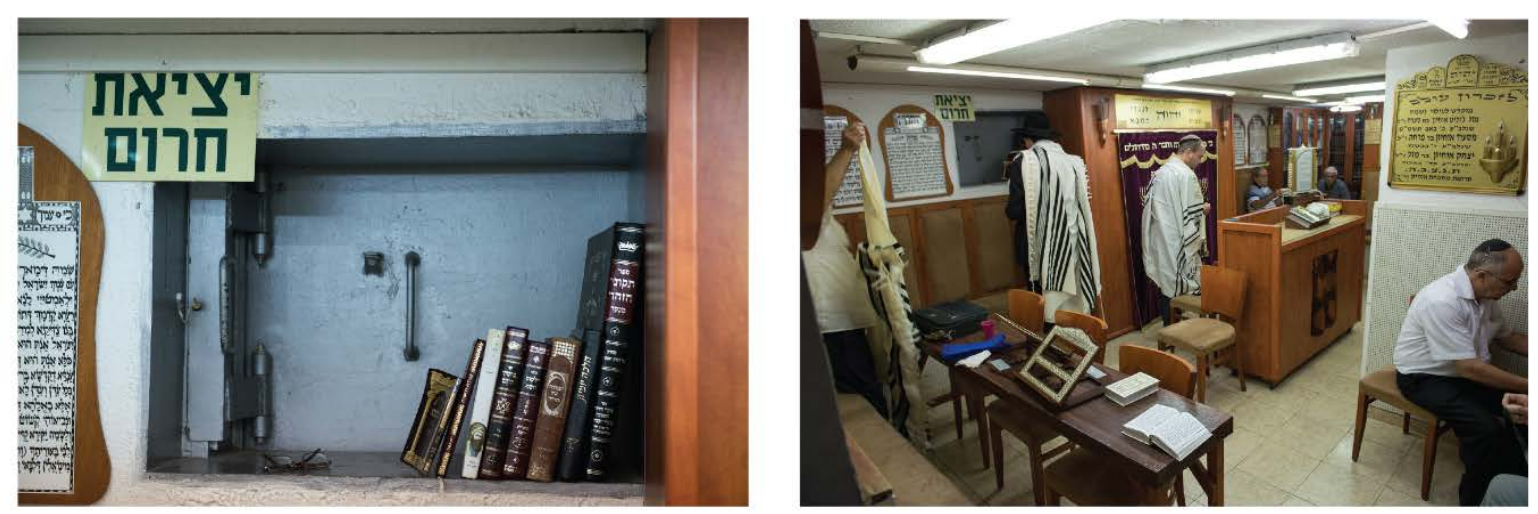

The crystallization of the Mizrachi identity, as a marginal identity that is isolated from the power structures within Israeli society, caused the founders to take action, as reflected in the following excerpt from a conversation with the founder: "Prayers in the synagogue are conducted according to the Mizrachi-Sephardi tradition. My children and I planned them. If I would have waited for them, do you think they would give me [land and money]?” The moment members of the Moroccan Jewish immigrant community understood that they were being discriminated against, they began to take action on the ground out of lack of choice. The intermediate liminal spaces provided them with a venue for activity that produces a non-dichotomous mixture of private and public.

A regular worshipper at the synagogue said the following: "I like this neighborhood style. In other synagogues, you feel like you're a stranger. Here, it’s like your own synagogue - you're home, and you love that man [pointing to Avitan]. He's a saint.” In this way, this small, intimate synagogue, located beside a private home, is an extension of the home and elicits emotional associations of home, belonging, and affection.

As in the case of the first synagogue discussed above, both the Torah scroll and the prayer service were imported from Morocco, as was the structure and the planning 
of the synagogue: "We lived the same - what we did in Morocco, we did in Israel. We came with a profession, we earned the same amount, we ate the same thing, and we dressed the same way.” The synagogue's location is small and extremely limited, and the possible range of planning was also limited, as attested to by Eliyahu Avitan: "You have to go with the shape of the bomb-shelter. We received assistance in planning the construction [from the city municipality]. There was a bathroom, but they removed it.”

Once again, however, the liminal structure of the synagogue in the bomb-shelter on the outdoor ground floor of the building upsets the planning definitions of private and public. "The city municipality doesn't want to give me a [formal] permit [to establish a synagogue] in order to not give me land. They told me to worship in the bomb-shelter in the meantime. 'The meantime’ has turned into 30 years.”

In this way, what is established here as temporary ends up being permanent, but also continues to mark the fragility of the cultural and physical structure in which people function. The conversion of a bomb-shelter into a synagogue created a variety of problems and conflicts, as attested to by the founder of the synagogue himself. On the one hand, it is the bomb-shelter of the residents and is usually locked, and only the police have a key. In times of war, when alert sirens are sounded, residents descend to the bomb-shelter. Later in the conversation, however, Avitan acknowledged that because it was a synagogue, the Arab residents would not take shelter there during the war and were not provided with another solution to ensure their safety during wartime.

The third synagogue, Or Torah, is a free-standing four-story building built by members of the Tunisian Jewish immigrant community who organized themselves into a non-profit organization. The synagogue initially operated out of a room in the private home of one of the community leaders. Later, community members petitioned the municipality to grant them land for a synagogue and were provided with a grain storage 
facility that was converted into a synagogue, which is the land on which the synagogue stands today. The building of the structure became a major focus of community action and a unifying force for the community, with community identity occurring vis-à-vis the construction process.

As opposed to the two previously discussed synagogues, Or Torah does not belong to a private residence. Nonetheless, it is perceived by the community as an extension of the home: "A synagogue is a community and spiritual center and a source of mutual help,” the synagogue's founder explains. The entry level, which constitutes a flexible space, is meant for study, meetings, and family events. The basement contains a kitchen, which was built for neighborhood families to use for special occasions. Here, too, the hardships faced by the Mizrachi Jewish population was of pivotal importance, and the kitchen has allowed them to host others and to maintain large families, even though most of the community lives in apartments that are 50-70 square meters in area.

Figure 9: Or Torah, the synagogue's main space, which is used for Torah study classes and family events.

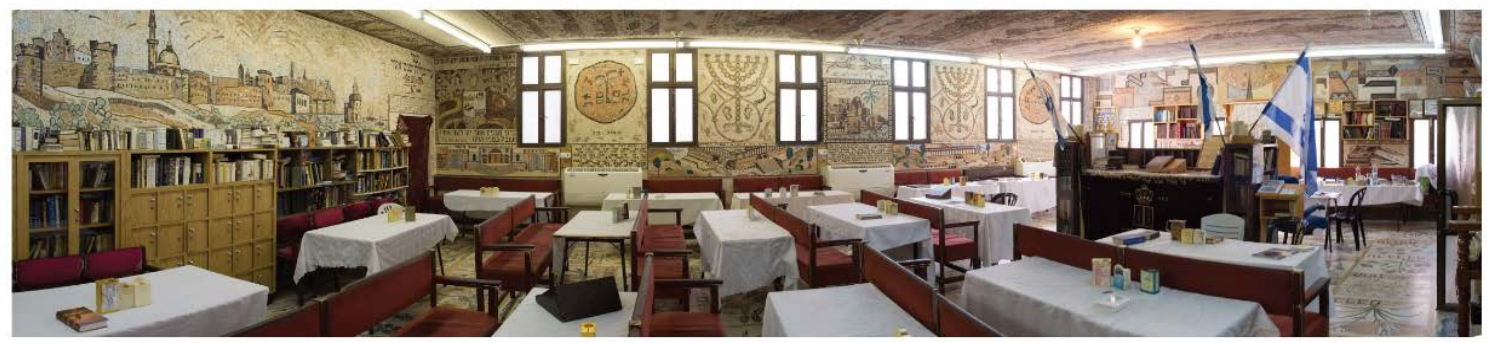

The founder's attitude to modern architecture and the formal planning and authorization process was wholly instrumentalist in nature. "We took on an architect," he told us. "He built the foundations and we received the permits. Then we fired him. The entire interior is ours.” In other words, this process created a situation in which the 
community made use of modern architecture to meet a minimal requirement of a bureaucratic-planning process.

The architect built the synagogue as a cube, which provided great flexibility for the synagogue's founders, who distinguished between the shell (the modernist cube) they needed to build in order to be granted the required permits and the content with which they would fill it. In the economically limited conditions in which he was operating, once the cubic structure was complete and at his disposal, the founder of the synagogue did not issue a tender for contractors. Rather, he approached the worshippers themselves and asked them whether they had any construction professionals in their families.

During this process, various artisans who had abandoned their crafts and became manual laborers when they immigrated to Israel began to emerge. The building of the synagogue gave these individuals, who never received a formal education and were not formally certified to work as construction professionals, a unique form of expression. One did the welding, another (a community member who actually lives in southern Israel) coated the doors of the ark with silver, and a third made the stained glass. The very process of designing the structure became an activity that recovered arts (in the sense of crafts) and knowledge that had been erased during the immigration process.

The limited scope of this study precludes examination and analysis of the multifaceted nature of this process, which created an innovative language of design that combined elements that were familiar to the founders from Tunisia with what they observed and adopted from architecture in Israel. This also became a source of pride for members and made the synagogue a site of pilgrimage for tourists. In other words, the result was a cultural and physical structure that integrated different traditions and 
languages of design to produce, as argued in the conclusion, a junction constituting an objective possibility - a point that helps better understand "what might have happened" - that is, how urban environments in Israel might have evolved.

\section{Causal Analysis}

As explained in the first part of this article, the final stage of the inquiry, after the identification of concepts emerging from the empirical findings (in this case, the concept of "publicness"), is to attempt to establish causality: In what set of contexts, and in light of what contexts, can exploring publicness teach about 'other' possibilities of spatial organization? This section is concerned with creating a hierarchy and a system of relationships among the proposed concepts, as illustrated in Figure 5.

All three synagogues incorporate a 'different' knowledge of the organization of public and private in broader urban space. In contrast to the dichotomous discourse that seeks to separate the private and the public (as clearly reflected, for example, in the practice of zoning), the informal synagogues reflect another option: a system in which private and public are not dichotomous but rather constitute two poles of a scale consisting of many different variations, including the public's entry into the private (as represented by the synagogue operating within a private home), the synagogue as a liminal location (between the private and the public, as represented by the synagogue located on the outdoor ground floor of an apartment building), and the synagogue that invites the home into the public (as represented by the community synagogue).

Figure 10: Three Forms of Organizing Space between Private and Public 


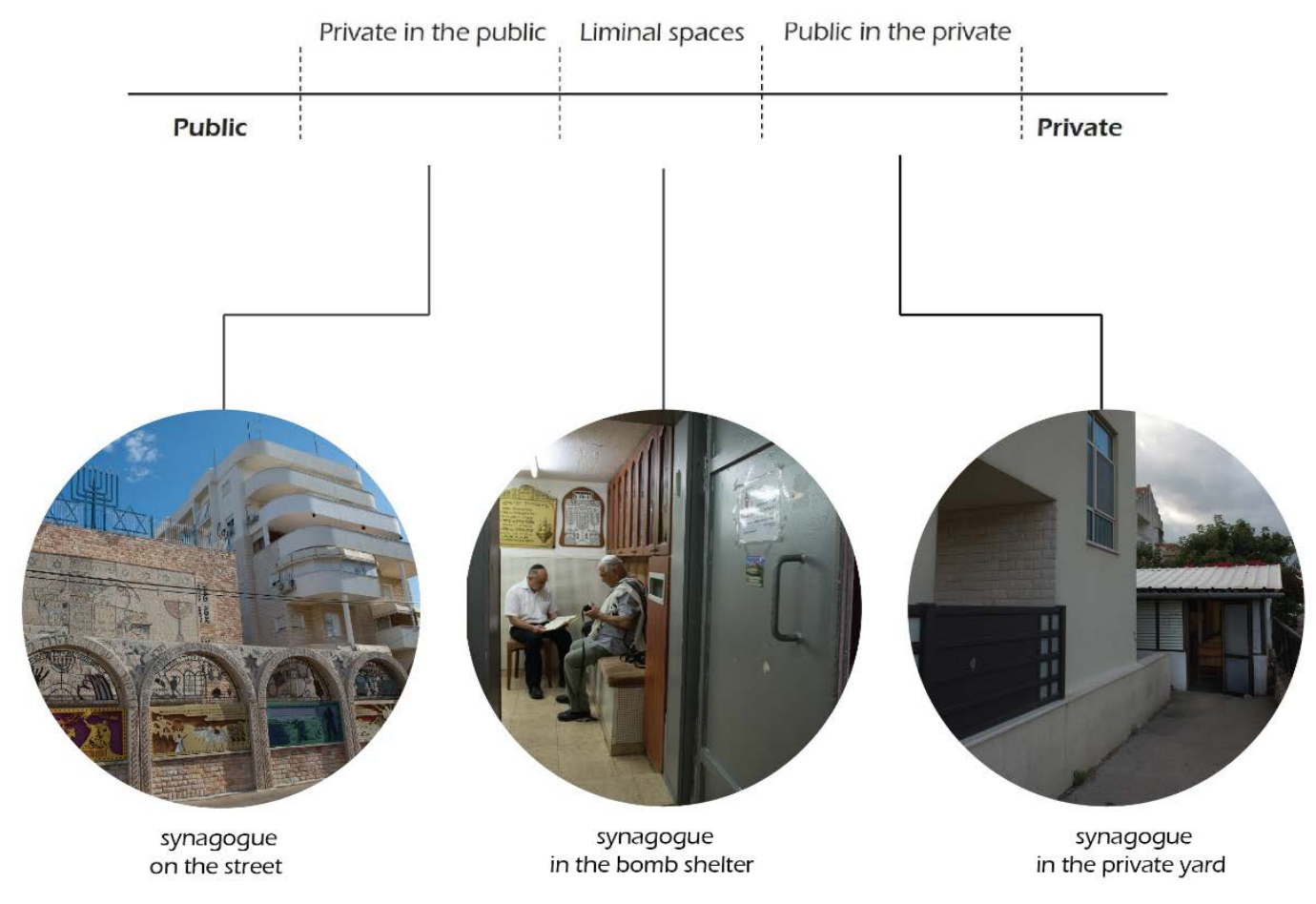

Causal analysis enables formulation of an objective possibility. The concluding argument is that the objective possibility represented and maintained by the configurations of the selected synagogues is a vanquished planning language referred to here as "intimate publicness.” The synagogues encourage public assembly, but the public in question is not drawn from the "society of strangers" that is a pillar of the modern city. Rather, it is an intimate publicness, a publicness that exists in differing circles of proximity. In the first instance, it applies to the category of religion and addresses Jews - not all Jews, but rather Jews of a certain ethnic group (Jewish immigrants of Yemeni, Moroccan, or Tunisian origin). In the second instance, it addresses members of a certain ethnic group who are also neighbors and who live side by side in the same neighborhood. In the third instance, it addresses the extended family and is an act of public organization that revolves around the immediate family, which maintains and preserves the charisma of the founding father. The fact that the publicness at play in all three examples is 'intimate publicness' allows the breaching of 
the dichotomous boundary between the private and the public; after all, the public attending the synagogue is an extension of the private and vise versa.

This study's analysis of the three synagogues points to explanatory variables that shed light on the conditions in which intimate publicness exists, and the major category identified in this context is class. As noted, Judeo-Arab communities have been relegated to the lower rungs of the ladder of socioeconomic stratification in Israel. The lack of material, resources, and political power in the municipal government resulted in necessity - as "a Jew cannot remain in a city for even a few hours without a synagogue to pray in.” In this way, the breaching of boundaries has occurred in a reality in which every resource at the disposal of the community and the individual must be maximized, and intimate publicness must be understood as a product of contexts of poverty and meagre resources.

Figure 11: Intimate Publicness, A Causal Analysis

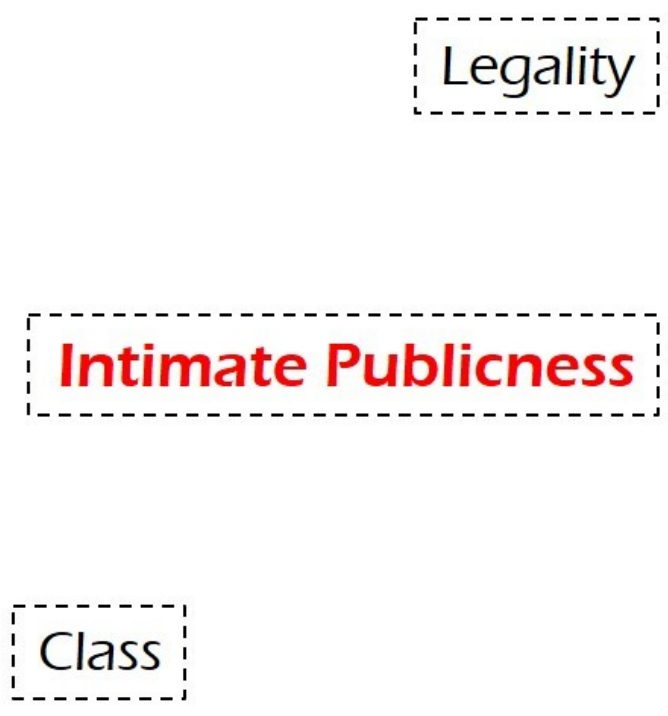

Intimate Publicness as an Objective Possibility 
This article contributes to critical thought regarding the meeting point between cities and society. By transposing the notion of objective possibility from the realm of time into the realm of space, this study offers a new-old methodology of urban investigation and illuminates objective possibility as other urban possibility. It is a response to the state of the critical academic community at the turn of the new millennium, in which different regimes of subjugation and marginalization, and the modern knowledge of urban planning, have emerged as tools of erasure, silencing subaltern groups and denying them the ability to articulate their needs and desires both in a sociological and an urban sense. It also adds to the critical thought on planning and urbanity by proposing a classical sociological theory based on the notion of objective possibility. As such, it offers both a theoretical framework and a methodological tool that is not confined to one particular space or empirical case study but rather helps better understand processes of erasure in general.

In this way, the article contributes to the continued development of critical theory in three ways. First, it goes beyond simply commemorating lost knowledge by recognizing and documenting it not merely as a site of memory or a reservoir of Orientalized knowledge but as lived and experienced spaces. Second, by recognizing and tracing roads not taken, it generates new perspectives from which to consider the ways in which the roads that were taken were materialized. Such perspective is the driving force behind critical thought, as it facilitates an outside vantage point that is typically difficult to create. And third, it enables articulation and assessment of the ways in which marginalized communities retain agency in the city as human beings and as members of a collective with the power to act in the social world and the built environment, ensuring that their voices, which may have been turned down, have not been silenced altogether. 
Importing the concept of objective possibility into urban issues stands not only to contribute to theoretical development in the realm of academia but also to planning in practice. Taken together, the presence of minorities (including refugees and immigrants) in modern cities, on the one hand, and the professional domination of urban planning, on the other hand, are responsible for the current mounting need to articulate the presence of 'different' environments. Such environments possess and generate cultural and economic knowledge regarding different issues, such as the nature and role of families, different kinds of division of labor, and unique conceptions of private and public and the relationship between the two, to name just a few.

This original approach challenges current trends in planning that emphasize Private-Public-Partnership (PPP) as a new progressive approach to planning and design. The analytic exercise of objective possibility sheds light on a different way of organizing public-private spaces and social relations, but this time based on a full understanding of the cultural and social conditions in which the idea of intimate publicness manifests itself in the built environment.

In addition, the notion of objective possibility also has the potential to contribute to urban conservation, based on its ability to prevent actualization of the Oriental visions that are so common to efforts to maintain the urban relics of other urban groupings. The investigation undertaken in this article deepens knowledge regarding the conditions in which specific architectures and planning languages can prosper and generate an actual lived environment. Focusing on the conditions in which such 'other' planning takes place transforms other urban languages into viable possibilities for the urban present and future. 
Abbasi, M. 2010. The Fall of Acre in the 1948 Palestine War. Journal of Palestine Studies 39 (4), pp. 6-27.

Bilu, Y. 2000. Without Bounds: The Life and Death of Rabbi Ya'aqov Wazana. Detroit: Wayne State University Press.

Breen, K. 2005. Negotiating the 'Iron Cage': Habermas, Arendt and MacIntyre in Response to Weber (Doctoral dissertation, Thesis (PhD), University of Edinburgh).

Chetrit, S. 2010. Intra-Jewish Conflict in Israel: White Jews, Black Jews. London and New York: Routledge.

Deshen, S. 1972. Ethnicity and Citizenship in the Ritual of an Israeli Synagogue. Southwestern Journal of Anthropology 28(1), pp. 69-82.

Galili, E., Rosen, B., Zviely, D., Silberstein, N. \& Finkielsztejn, G. 2010. The Evolution of Akko Harbor and its Mediterranean Maritime Trade Links. Journal of Island \& Coastal Archaeology 5, pp. 191-211.

Garzuzi, J. 2006. Residential Patterns and Socio-Economic Characteristics of the Arab Population in Neighborhoods of Acre (Master thesis, University of Haifa).

Heidelberger, M. 2001. Origins of the logical theory of probability: von Kries, Wittgenstein, Waismann. International Studies in the Philosophy of Science, 15, $177-188$.

Kong, L., 2002. In search of permanent homes: Singapore’s "house” churches and the politics of space. Urban Studies, 39, no. 9: 1573-1586.

Leon, N. 2009. Ethnic Synagogues of Mizrahi Jews in Israel: Ethnicity, Orthodoxy, and Nationalism. Sociological Papers 14: 6-21. 
Leon, N. 2010. Ethnicity, Ultra-Orthodoxy, and Gender in the Multiple-Ethnic Synagogue in Israel. Kenishta - Studies of the Synagogue World 5, pp. 191-220 (Hebrew).

Mantysalo, R. 2002. Dilemmas in Critical Planning Theory Article in The Town Planning review 73(4):417-436

Philipp, T. 1990. The Rise and Fall of Acre: population and economy between 1700 and 1850. Revue du monde musulman et de la Méditerranée, 55(1), 124-140.

Piroyanski, D. 2014. Ramle Remade, The Israelisation of an Arab town 1948-1967. Tel Aviv: Pardes Publishing.

Ram M. and Aharon-Gutman, M. 2016 "Sanctified strongholds: urban synagogues and the politics of change in contested urban environments." Journal of Economic and social Geography 11 JAN 2017, DOI: 10.1111/tesg.12231

Reiss, J. 2009. "Counterfactuals, Thought Experiments, and Singular Causal Analysis in History". Philosophy of Science 76: 712-723.

Ringer, F. 2002. Max Weber on Causal Analysis, Interpretation, and Comparison. History and Theory 41: 163-178.

Slyomovics, S. 1998. The Object of Memory, Arab and Jew Narrate the Palestinian Village, Philadelphia: University of Pennsylvania Press

Stanley Waterman, "Pre-Israeli Planning in Palestine: The Example of Acre." The Town Planning Review, Vol. 42, No. 1 (Jan., 1971), pp. 85-99.

Staples, M. 1999. From Pillar to Post: Regional heritage and the erasure of Modernist architecture, Rural Society, 9:1, 367-377

Torstrick, R. 2000. The Limits of coexistence. Identity politics in Israel. Michigan 
University Press: Michigan.

Tzfadia, E. \& Yacobi, H. 2011. Rethinking Israeli Space: Periphery and Identity. New York: Routledge.

Waterman, S. 1975. Early Post-State Planning in Israel: The 1949 Plan for Acre. Horizons in Geography 1, pp. IX-XVIII.

Waterman, S. 1971. Pre-Israeli Planning in Palestine: The Example of Acre. The Town Planning Review 42(1), pp. 85-99.

Weber, Max. 1949. The Logic of Cultural Sciences. In The Methodology of the social sciences, pp. 169-188. New York: The Free Press.

Weber, Max. 1959. Ideal type in Stanley H. Udy, Jr. " 'Bureaucracy' and 'Rationality' in Weber's Organization Theory: An Empirical Study." American Sociological Review, Vol. 24, No. 6, pp. 791-795

Weber, M. 1978. Economy and society: An outline of interpretive sociology. Univ of California Press.

Weiss, Y. 2011. A Confiscated Memory: Wadi Salib and Haifa's Lost Heritage. New York: Colombia University Press.

Yaad, D. 2008. Blueprint for Acre: Conclusive Document. Acre: Acre Municipality (Hebrew).

Yaad, D. 2008. Blueprint for Acre: Conclusive Document. Acre: Acre Municipality (Hebrew). 
${ }^{\mathrm{i}}$ Interview with Moshe, a representative of the Municipal Religious Council, September 13, 2013 (conducted by the authors).

ii Ibid. 